\title{
Vrou as beeld van God: Vanaf die Reformasie tot die twintigste eeu
}

\author{
Yolanda Dreyer \\ Departement Praktiese Teologie \\ Universiteit van Pretoria
}

\begin{abstract}
Woman created in the image of God: From the Reformation through the twentieth century

The purpose of this article is to trace how woman has been represented in the history of theology, in the period stretching from the Renaissance to the feminist movement of the twentieth century, as the image of God. The focus is on the views of Luther, Calvin, Schleiermacher, Bonhoefer, Brunner and Barth. As far as the feminist movement is concerned, attention is paid in particular to the views of Daly, Coll and Ruether. The discussion proceeds from the presupposition that, apart from the master narrative (the patriarchal-hierarchical perspective), a counter-narrative (a more egalitarian perspective) is also present in the Bible.
\end{abstract} These two perspectives form the criterion according to which woman as image of God has been traced in the history of theology. The article has been written with a view to pastoral interaction with women.

\section{VANAF ARISTOTELES TOT DIE RENAISSANCE}

Gedurende die Renaissance vind daar vanaf die Aristoteliese denke dat vroue niks anders is as "gebreklike mans" nie, 'n verskuiwing plaas na die siening dat die vroulike geslag in sigself normaal en natuurlik is. Daar is egter steeds geoordeel dat die vroulike geslag swakker en meer broos is as die manlike, en daarom beskerm moet word (kyk Maclean 1980:28-46). 'n Verdere saak wat aan die orde was, is die verskuiwing van die Aristoteliese siening dat die fetus die gevolg was van alleenlik die man se saad na die nuwe siening dat vroue ook 'n bydrae daartoe lewer (kyk Maclean 1980:35-37). Ander 
kwessies van die dag was of vroue die vermoë het om te regeer, of God dit sou wil en, indien wel, wat hulle verhouding tot mans dan sou wees (Douglass 1991:228-229). 'n Paar vroue, soos koninginne en adelike vroue, het wel in dié tyd heelwat politieke en sosiale mag gehad (vgl Clark 1979). 'n Groot aantal vroue het egter omgekom in die heksejagte wat selfs tot in die tyd na die Reformasie geduur het. Die idee van Aristoteles dat 'n vrou 'n "gebreklike man" was, het bygedra tot die dood van vroue wat in die vyftiende tot sewentiende eeu van heksery verdink is (Coll 1994:73). Die twee Dominikane, Kramer en Sprenger, wat opdrag van die pous gekry het om die regulasies ten opsigte van heksery op te teken, stel dit so: "All witchcraft comes from carnal lust which is in women insatiable" (Summers 1971:123; vgl ook Daly 1979; Dworkin 1974).

In intellektuele kringe was daar wyd uiteenlopende vooronderstellings oor vroue. Vroue is soms genadeloos geminag en ander kere weer op oordadige wyse geprys. 'n Algemene vraag in die debat was of vroue se swakheid inherent was of die gevolg van sosialisering, naamlik gebrekkige onderwys en min ervaring buite die huis (vgl Kelly 1982; Douglass 1985:66-73). In 1598 verskyn daar 'n verhandeling, getitel 'n Nuwe dispuut oor vroue, waarin bewys word dat hulle nie mense is nie! Hierdie geskrif word gewoonlik aan Valens Akidalius toegeskryf. Dit is 'n satire en is ernstig gedebatteer deur teoloë, dokters en regsmense. Die teks en die besware daarteen is tot laat in die agtiende eeu nog gepubliseer (vgl Maclean 1980:12-13; Fleisher 1981:107-120).

Die vraag oor die natuur van vroue was dus relevant in die tyd van die hervormers Martin Luther en Johannes Calvyn. Luther en Calvyn, wat hulle op die gesag van "die Skrif alleen" beroep het, het anders te werk gegaan as die Middeleeuse teoloë. Hulle kon hulle nie heeltemal distansieer van die tradisie nie, maar het tog probeer om opnuut met die Skrrif as beginpunt na die posisie van vroue te kyk. Met die kennis van Grieks, Hebreeus en tekskritiek wat die Renaissance meegebring het, is daar heelwat minder gebruik gemaak van allegoriese uitleg as in die Middeleeue. Daar was ook ' $n$ veel groter belangstelling in die historiese konteks van die Skrifgedeeltes (Douglass 1991:230). Waar vroeère teoloë sterk gebruik gemaak het van allegorie in hulle bespreking van vroue (kyk Børresen 1981:26-29), het die aard van die bespreking nou verander. Met die klem op "die Skrif alleen" kon die hervormers nie meer na hartelus spekuleer soos die Middeleeuse skolastiek voor hulle gedoen het nie. Vanuit hierdie nuwe perspektief “... 
wurde die Allegorese nur durch den Gesichtspunkt eingeschränkt, daß sie nichts zutage fördern dürfe, was nicht auch sonst direkt durch die Schrift belegt ist und zum Inhalt des christlichen Glaubens gehört" (Ebeling 1971:61; vgl ook Oberman 1963:50-55; Bouwsma 1988:106-107, 157).

\section{LUTHER}

Luther het nie ' $n$ volledige bespreking van die uitdrukking "beeld van God" nagelaat nie. Sy kommentaar op Genesis kan egter vir dié doel nagegaan word. Adam en Eva is volgens hom geskape na die beeld van God en het as gevolg daarvan beskik oor 'n besondere kennis en vermoë. Met die sondeval het hulle dit verloor. Die evangelie bring egter herstel van die beeld van God in die mens, en daarmee saam die hoop op die ewige lewe. Hierdie herstel is nog nie afgehandel nie, maar sal finaal voltooi word wanneer die koninkryk van God aanbreek. Dan sal die krag van die beeld van God in mense vernuwe word en sal hulle vry wees van vrees. Hulle sal heers oor alles (kyk Douglass 1991:231232). Luther verwys meesal saam na Adam en Eva, maar noem Eva wel ook afsonderlik: "Eva hct beskik oor hierdie vermoëns op 'n gelykwaardige wyse aan Adam" en "( $t$ )herefore she not only heard these things from Adam, but her own nature was pure and full of the knowledge of God, so that by herself she understood and reflected on the word of God" (D Martin Luthers Werke, Weismar kritische Ausgabe $=W A 42,50=$ Koffmane \& Reichert 1911:50, in Douglass 1991:233). Aan die een kant beskou Luther klaarbłyklik vroue as ten volle menswaardig. Hy verwerp die verwysings in die Talmoed na die eerste mens as 'n tweeslagtige wese wat later in manlik en vroulik geskei het. Hy verwerp ook Aristoteles se tipering van vroue as "gebreklike mans" of "monsters". In sy verdere kommentaar op Genesis 1:27 sê Luther:

... dit lyk of die vrou 'n ietwat ander soort wese is as die man, omdat sy nie dieselfde [anatomiese] kenmerke het nie en 'n natuur het wat swakker is. En hoewel Eva 'n mees buitengewone skepsel was, soortgelyk aan Adam omdat hulle na die beeld van God geskape is, dit wil sê in geregtigheid, wysheid en deugdelikheid, het sy steeds vrou gebly. Net soos die son meer buitgewoon is as die maan (hoewel die maan self 'n buitengewone entiteit is), is die vrou, hoewel self 'n baie mooi produk van God, steeds nie gelyk aan die heerlikheid 
en waardigheid van die man nie (WA 42, 51-52, in Douglas 1991:134; my vertaling van die Engeis).

Die satan het vir Eva genader en nie vir Adam nie omdat, hoewel hulle gelyke goeie eienskappe gehad het vanweë die beeld van God, Adam tog beter en sterker was as Eva. Die slang het dus die swakker deel van die menslik natuur genader (Douglass 1991:235). Luther was daarteen dat vroue ampte beklee of in die openbaar funksioneer. Hy haal 1 Timoteus 2:11 aan as regverdiging van hierdie standpunt. Dit gaan vir hom nie oor vroue se onvermoẻ nie. Luther meen dat Paulus geglo het vroue kan ook slim wees. Maar hy is bang dat vroue in die openbaar teen hulle mans sal redeneer en argumenteer. Luther verwys na vroue in die Bybel wat wel gesag gehad het, maar beklemtoon dat hulle ongetroud was. Die getroude vrou moet nie gesag hê oor haar man nie. Tog bied hy nêrens vir 'n ongetroude vrou die moontlikheid om openbare ampte te beklee nie (kyk Douglass 1991:241).

\section{CALVYN}

Calvyn is ' $n$ "tweede generasie hervormer" en kon dus baat by die eksegetiese en teologiese werk van Luther en ander. Sy opleiding was net so humanisties georiënteer as Luther s'n. Calvyn wil ook, soos Luther, direk met die Skrif werk en nie uit die Middeleeuse teologie en klassieke filosofie nie. Hy het geworstel met die spanning tussen Genesis 1 en 1 Korintièrs 11 oor die beeld van God en sy oplossing was verrasend modern (Douglass 1991:243-245). In die Institusie verduidelik hy dat Adam goeie eienskappe gehad het, hulle verloor het met die sondeval, dat Christus daarvoor betaal het en nou die gelowige kan bring tot ewige lewe. Eva word nie genoem nie. Adam as man is die verteenwoordiger van die mensheid. Vroue is dus onsigbaar. Dieselfde soort swygsaamheid word aangetref ten opsigte van Eva se skuld vir die sondeval. Die Institusies beklemtoon die eenheid van die mensheid en is klaarblyklik nie geinteresseerd in die verskille tussen mans en vroue nie: Daar is net een verwysing na vroue se ondergeskiktheid in die Institusies. Dit is in 'n bespreking van slegte heersers. Calvyn se oproep is dat mense alle gesag moet gehoorsaam ten spyte van die feit dat heersers verkeerd kan wees. Dominansie is klaarblyklik volgens Calvyn gewoon 'n manlike 
prerogatief. Die beeld van God in die mens kan gesien word in die volmaaktheid van die mensheid voor die sondeval.

Calvyn tref geen onderskeid tussen die terme "beeld" en "gelykenis" nie. Wat hom betref, is dit gewoon Hebreeuse woorde met ekwivalente betekenis. Volgens hom word die beeld van God aangetref in die mens se siel. Sedert die sondeval is dit egter moeilik om die beeld van God in die verdorwe menslike natuur raak te sien. Daarom moet dit gesien word "in Christus", die tweede Adam wat die integriteit van die mens herstel en die mens vernuwe tot die beeld van God. Dat vroue se liggame verskillend is, beteken nie dat hulle nie beelddraers van God kan wees nie, want die beeld van God is ' $n$ geestelike aangeleentheid (Douglass 1991:246). Interessant is Calvyn se siening van 1 Korintiërs 11. In 1536 skryf hy dat die sake wat in I Korintiërs genoem word, nie as wesenlik nie, maar slegs as gebruike gesien moet word.

Is godsdiens te vind in die tjalie van 'n vrou, sodat dit vir haar sonde is om met ' $n$ onbedekte kop uit [haar huis] te gaan? Is daardie bepaling van Paulus [1 Kor 14:34] oor die vrou wat moet stil bly, só heilig dat dit nie verbreek mag word sonder dat dit as 'n baie groot oortreding geag word nie? ... Hoegenaamd nie ... laat die gevestigde gebruike van die omgewing, en ten slotte menswaardigheid self en die reël van kuisheid, voorskryf wat gedoen of vermy moet word (Inst 6,33 = OS I 256-257; vertaling van Engels).

Die hoofbedekking van vroue is dikwels ten tye van die Reformasie beskou as onbelangrik, maar Calvyn staan alleen as hy die saak van vroue se stilte in die kerk sien as 'n kwessie van gebruike en nie as 'n beginselsaak nie (kyk Douglass 1991:247). Wanneer hy die spanning tussen 1 Korintiërs 11:7 en Galasiërs 3:28 bespreek, sien hy die verskil in die konteks van die twee gedeeltes in. Vir hom verwys Galasiërs 3:28 na die koninkryk van God en in Korintiërs gaan dit oor die aardse bestel. In die aardse bedeling aanvaar Calvyn die man se dominansie oor vroue as 'n sosiale gegewe. Calvyn se beredenering van die saak is egter meer kompleks as Luther se eenvoudiger siening dat ondergeskiktheid vroue se straf vir die sondeval is en dat dit daarom sal duur tot die einde van die tyd (vgl Potter 1986:725-730). 
Saam met die mediese dokters van die Renaissance verwerp Calvyn Aristoteles se siening van die vroulike fisiologie. Anders as Luther, aanvaar Calvyn dat vroue ook met "saad" 'n bydrae lewer tot die nageslag. Die "volmaakte man" van Efesiers 4:13 is volgens Calvyn se interpretasie nie 'n probleem vir vroue nie. Hy verstaan dit Christologies. Christus self is die volmaakte man. Alle Christene, mans en vroue, streef daarna om soos Christus te probeer wees. Tog sien Calvyn vroue nie in die ampte nie. Die rede wat hy aangee is egter nie gegrond op ' $n$ teologiese of antropologiese beginsel nie. Hy verwys naamlik in dié verband na 1 Korintiërs 11 , wat hy as gebruike en reëlings van die tyd en kultuur beskou, en nie as ewige waarhede nie. Hierin verskil hy dus van Luther wat ondergeskiktheid beskou as vroue se natuurlike staat vanweë die sondeval (Douglass 1991:248; kyk ook Ruether 1991:269).

Calvyn se verduideliking van die gesag wat vroue soos Debora gehad het, is dat dit beskou moet word as buitengewone dade van God. Buitengewone dade van God staan nie in opposisie tot die gewone menslike orde nie. Calvyn oorweeg egter dat vroue se ondergeskiktheid as sodanig hulle nie noodwendig daarvan weerhou om gesag te dra en te leer nie, aangesien profete en leraars ook ondergeskik is aan konings en ander regeerders. Maar die vrou se posisie is anders, want "sy is van nature gebore om te gehoorsaam. Immers, alle verstandige mense het nog altyd 'n vrou se regering as afgryslik verwerp" ( $C O$ 52, 276; vertaling van Engels). Hoewel Calvyn dus nie die tradisionele argument van vroue se minderwaardige natuur wil volg nie, kom sy oordeel op die ou end maar weer neer op die minagting van vroue se natuur. Daarby beroep Calvyn hom op die vanselfsprekendheid van algemene kennis en instemming oor die saak. Ek het vroeër (2000:???) daarop gewys dat so 'n argument 'n teken is van vasgevang wees in institusionalisering.

Oor die vrou as beeld van God in 1 Korintiërs 11:7 (in vergelyking die skeppingsverhale in Genesis) meen Calvyn dat Paulus alleen na die huislike situasie verwys. In Genesis, aan die ander kant, gaan dit vir hom oor die glorie van God wat voortgedra word in die menslike natuur. Die mens, man en vrou, is draer van die beeld van God. Die man alléén verteenwoordig minder as die volle mensheid. Hier verskil Calvyn van die Middeleeuse teoloë vir wie die man op sy eie wel volle mensheid verteenwoordig. Vroue is volgens Calvyn ook beeld van God, maar slegs in 'n tweede graad (secundo gradu). 
Die man is verantwoordelik vir haar en sy is ondergeskik aan die man. Maar as Calvyn die frase bespreek dat die vrou "by hom pas", sien hy die vrou as maat, lewenslange kameraad. Diegene wat dus redeneer dat vroue net gemaak is vir voortplanting, is volgens hom verkeerd. Calvyn het die Institusies 'n paar maal verwerk. Opvallend is dat, in die laaste verwerking kort voor sy dood, daar geen leer van vroue as beeld van God in die tweede graad meer is nie en ook nie van vroue se inherente ondergeskikte natuur nie (Douglass 1991:249-251).

Hoewel verdere ontwikkelings in die sosiale filosofie plaasgevind het, het die moderne Protestantse geloofgemeenskap die ontwikkelings van die Reformasie geërf. Teenoor die hervormers het die Puriteine geoordeel dat "bekeerde vroue" gesag kon uitoefen in die kerk as predikers en profete omdat hulle herstel is tot geestelike gelykheid. Maar selfs die Puriteine het die getroude vrou steeds gesien as onder die gesag van haar man. Hulle het egter wel 'n bedeling van gelykheid in die kerk vir die vrou as leraar voorgestaan (kyk Ruether 1991:269).

Die Protestante se historiese siening van die Skrif maak dit onmoontlik om vas te hou aan idees van 'n liggaamlose staat van die siel (Ruether 1991:269). Voor die sondeval was daar twee beliggaamde mense. Ook die siening dat "rede" en "heerskappy" twee sake inherent aan beeld van God is, kom tydens die Reformasie in onguns.

\section{DIE VERLIGTING}

In die Verligting ontwikkel die idee van 'n "oorspronklike staat" van die natuur toe alle mense gelyk was. Samelewings het later wegbeweeg van hierdie oorspronklike staat en onregverdige bevoorregting en ondergeskiktheid ingevoer in menseverhoudings. Revolusionêre liberalisme wou die feodale stelsel, wat gebaseer was op die bevoorregting van die aristokrasie, omverwerp. Die doel waarna gestreef is, was 'n samelewing soortgelyk aan die oorspronklike natuurlik staat. Verlossing as herstel van die beeld van God in mense, word nou 'n sosiale projek wat binne die geskiedenis deur mense aangepak kan word. Vroue is egter nie ingesluit in hierdie menseregteprojekte nie. Die rede en heerskappy was steeds eienskappe wat beperk is tot mans. Slawe, kinders of mans sonder eiendom, is ook nie ingesluit nie. Die patriargale idee van die manlike hoof van die familie as verteenwoordigend van die mensheid en van sy gesin is dus, ten spyte van 
grootliks veranderde denke, voortgesit. Die Verligtingsdenke het egter wel die klimaat verskaf waarbinne die feminisme begin werk het om vroue as outonome persone ingesluit te kry by burgerregte. Met die beëindiging van slawerny, is burgerregte uitgebrei na alle volwasse mans. Sosiale denke het al hoe meer begin beweeg in die rigting van individualisme. Mense wat tradisioneel afhanklik was van die manlike familiehoof het nou outonome persoonskap en volle burgerregte vir hulleself opgeëis (kyk Ruether 1991:269270).

\section{DIE ROMANTIEK}

Die negentiende-eeuse Romantiek het op verskillende maniere teen die denke van die Verligting gereageer. Teenoor die liberalisme se model van die menslike natuur as rede en morele wil, stel die Romantiek ' $n$ verskeidenheid van menslike tipes. Mense is geklassifiseer volgens ras, sosiale stand en geslag. Klem word gelê op die "teenoorgestelde" nature van mans en vroue. Mans is rasioneel aktief, terwyl vroue as emosioneel en passief gesien is. Met die sekularisasie van die openbare sfeer is godsdienstige vroomheid en moraliteit meer aan vroue oorgelaat. Mans is gesien as meer sekulêr. Vroue se vroomheid en moraliteit was nodig om mans op hierdie gebied te help. Vroue word gesien as die geslag wat meer natuurlik "soos Christus" is: morele suiwerheid, geduldige lyding en altruïstiese diens aan ander. Dit sou impliseer dat vroue nou weer die meerderwaardige geslag sou wees. Maar juis hulle morele en spirituele superioriteit maak hulle ongeskik vir die ruwe take van mag (kyk Ruether 1991:169-171). In die romantiese vorm daarvan het die twee-nature antropologie gelei tot die ondergeskiktheid en die verheerliking van die vroulike. Die mystique van die goeie moeder, suster en vrou het vroue afgesny van die openbare sfeer en beperk tot die private sfeer van die huis waar hulle 'n veilige hawe skep vir mans wat moet uitgaan om te werk in die wrede en genadelose wêreld (kyk Coll 1994:74-75). Vroue se deugde moet dus beoefen word in die sfeer buite die geskiedenis. "These notions of woman's "sacred" nature, too pure and delicate for the male secular world, became a stock argument against allowing women rights in public society" (vgl Douglass 1977).

Tydens die periode van die Romantiek staan Friedrich Schleiermacher egter uit as 'n uitsondering op die reël. Iemand soos Marilyn Chapin Massey poog om in haar werk 
Feminine soul: The fate of an ideal (1985) aan te toon dat ons by Schleiermacher 'n goeie voorbeeld het van hoe vroue-ervaring die slagoffer word van romantisering en daarom van deprivasie van 'n simmetriese interaksie met 'n man (vgl ook Elizabeth Clark \& Hebert Richardson 1977:173-190). 'n Kenner van Schleiermacher, Dawn DeVries (1996: 551), meen egter dat ons in hierdie standpunt te doen het met anakronistiese vrae "imposing a definition of "feminism" taken from the latter part of the twentieth century on texts written in the first decades of the nineteenth." Volgens Ruth Drucilla Richardson (1991:182) kan Schleiermacher eerder beskou word as "a harbringer or forerunner of feminism." Dit is daarom interessant om kennis te neem dat Karl Barth (1962:136-158) in sy bespreking van Schleiermacher se beroemde "oukersaandgesprek" gesê het dat dit juis Schleiermacher se kombinasie van godsdienstige ervaring en sy visie op vroue is wat 'n teken is van wat presies "verkeerd" sou wees in sy teologie.

Schleiermacher se siening oor vroue het aandag gekry in verskillende werke. Een van hierdie werke is inderdaad (Engelse titel) Christmas Eve: Dialogue on the incarnation, geskryf in 1806. In hierdie boekie word die spanning tussen die vraag na die historiese Jesus en die konvensionele dogma rondom die vleeswording van Jesus ingetrek in 'n fiktiewe familiegesprek op 'n ou kersaand. Die skrywer-teoloog assosieer homself nie met die vertelde karakters wat of die kliniese rasionalisme van die liberalisme of die rigiede ortodoksie verteenwoordig nie. In hierdie teks kry ons wel 'n voorbeeld van hoe Schleiermacher die konsep "godsdiens as 'n absolute afhanklikheidsgevoel" in sowel 'n histories-kritiese as 'n kerklike konteks verstaan. Volgens Keith Clements (1987:195) is hierdie werk "one of the most humanly charming pieces of serious theology ever written, as it vividly portrays young and old, men and women, sceptic and pietist, enjoying music and conversation and sharing their thoughts on the significance of the joy of the Christmas season." Drucilla Richardson (1991:133-164) het op grond van haar studie van hierdie werk (asook van o a Confidential letters on Friedrich Schlegel's Lucinde [1800] waarin hy respondeer op die idees van sy Berlynse kunsternaarsvriend en digter, Friedrich Schlegel - kyk Clements 1987:19-22) tot insiggewende gevolgtrekkings gekom. Sy toon aan dat Schleiermacher die terme Anschauung as 'n bewuste manlike Geschlechtscharakter en Gefühl as 'n bewuste vroulike Geschlechtscharakter gebruik. Schleiermacher herdefinieer hiermee in ' $\mathrm{n}$ sekere sin die totale agtiende-eeuse (eintlik die 
hele voorafgaande agrariese periode se) etiek deur die begrip "kuisheid" (Schaamhaftigkeit) anders te gebruik. Vir hom het dit nie meer betrekking op "preutse kuisheid" wat 'n spesiale eienskap van slegs die vroulike geslag sou wees nie. Schleiermacher gebruik die term in die sin van respek vir die vryheid van ander mense, 'n sensitiwiteit vir hulle broosheid, dit wat beide geslagte karakteriseer in hulle onderlinge sosiale interaksie.

Schleiermacher was bekend dat hy vriendskap en intelelktuele gesprek nie net met mans nagestreef het nie, maar ook met vroue. Onder hulle was veral sy suster Charlotte von Kathen, die getroude Jodin Henriette Herz en Eleonore Grunow, die vrou van 'n Berlynse pastor. Schleiermacher en Eleonore het 'n besondere geneentheid vir meklaar gehad (kyk Clements 1987:21). In 'n brief aan Leonore in 1802 skryf Schleiermacher "for it is through the knowledge of the feminine heart and mind that I have learnt to know what real worth is" (Clements 1987:21). Aan sy suster Charlotte skryf hy: "if ever I find myself sportively indulging in an impossible wish, it is, that I were a woman." Oor hierdie opmerking sê Clements (1987:22):

The reason Schleiermacher gives for this fantasy, however, should be noted. It is the opportunity, as he sees it, for women to retain inner feelings of love and imagination as compared with men who are so quickly lost and occupied in activity. Protestant machismo ("Rise up, O men of God!") has long been embarrased by feminine humanity, and perhaps, Schleiermacher has an important speech to deliver in this direction as well. Maybe feminist theology will offer another new perspective on Schleiermacher.

\section{POST-AUFKLÄRUNG}

Teenoor die optimistiese mensbeeld van die Aufklärung, liberalisme en romantiek, keer ontnugterde Duitse Protestantse teoloë na die eerste wêreldoorlog terug na Reformatoriese leerstellings van die radikale sondigheid van die mens. Hulle is egter ook beïnvloed deur die nuwe sosiale filosofie van die tyd, onder andere deur Martin Buber (1984) se "ek-U" konsep. Buber onderskei skerp tussen subjek-subjek en subjek-objek relasies. Laasgenoemde is ontmenslikend, terwyl wedersydse respek deur middel van subjeksubjek verhoudings uitgedruk word. Buber se model oorbrug die kloof tussen individualisme en samelewing wat as 'n struikelblok in die Europese denke gefunksioneer het. 
Die subjek-subjek verhouding verskaf 'n model om outonomie en gemeenskap steeds saam te kan sien. Maar dan moet daar duidelik ingesien word dat daar 'n wesenlike verskil tussen subjek-objek en subjek-subjek relasies is. Hierdie perspektief het 'n bepalende uitwerking op teoloë se siening van die beeld van God begin uitoefen (kyk Ruether 1991:271).

Protestantse teoloë (dikwels geëtiketteer as "neo-ortodoks") benader Genesis 1:27 nou met 'n paar nuwe sake op die agenda. Teenoor die Rooms-Katolieke siening dat die sondeval die beeld van God verwring het, meen hulle dat die beeld van God heeltemal verlore gegaan het. Die mens het alle moontlikheid om op 'n natuurlike wyse by God uit te kom, verloor. In die mens is daar geen aanknopingspunt vir redding te vind nie. Die mens is van God alleen afhanklik vir verlossing. Ook word 'n skerp skeiding tussen die Goddelike natuur en die menslike natuur getref. Daar is geen sprake dat die mens op enige manier deel in iets van die Goddelike natuur nie. Van 'n analogia entis is daar nie sprake nie. Daar word ook skeiding gemaak tussen natuur en geskiedenis, tussen mens en dier. Al wat mense uniek maak en in die opsig "soos God" laat wees, is hulle vermoë tot relasies tot ander subjekte. Die beeld van God in die mens word in hierdie denke gedefinieer as analogia relationis en word onderskei van die Rooms-Katolieke analogia entis. Patriargale konsepte van manlik en vroulik as rede/siel teenoor liggaam en heerser teenoor ondergeskikte is in wese subjek-objek relasies (Ruether 1991:271).

Vervolgens kyk ek vlugtig na die ontwikkeling van die konsep "beeld van God" as analogia relationis by bekende Reformatoriese teoloë van hierdie tyd om te sien wat hulle insigte bygedra het vir die menswaardigheid van vroue en hoe dit deurgewerk het, al dan nie, in die praktyk van vroue se situasie. Ek steun in hierdie verband op veral die werk van Rosemary Radford Ruether (1991:272-274). Dietrich Bonhoeffer ontwikkel die idee van die beeld van God as analogia relationis verder. Hy sê daaroor (Engelse vertaling is alleen beskikbaar): "The likeness, the analogy of man to God, is not analogia entis but analogia relationis ... The relation of creature with creature is a God-given relation because it exists in freedom and freedom originates from God" (Bonhoeffer 1959:37). Uniek aan die menslike natuur is dat dit bestaan in relasie. God het die mens geskape vry van die determinisme van die natuur, en vry vir relasie met mekaar. Hierdie vryheid het verlore gegaan in die sonde, maar is herstel in Christus. Wat opvallend is, is 
dat Bonhoeffer nie die konsekwensies hiervan toegepas het op die verhoudings tussen die geslagte nie. Hy verwys deurgaans na die vryheid tot relasie met die "broer". Wanneer hy die sondeval bespreek, word dit duidelik dat hy vroue steeds beskou as in wese "swakker" as mans. Dit is dan die rede waarom die slang die vrou eerste benader het (kyk Bonhoeffer 1959:33-38, 76).

Ook Emil Brunner bou die konsep "beeld van God" uit sodat dit betrekking kan hê op ' $n$ analogia relationis. Brunner, soos Bonhoeffer, is bewus van die probleem wat die gelykheid van subjekte veronderstel in die $e k-U$ konsep. Hy gebruik ook die term "broer" vir die Ander. Sy konsep van die verhouding tussen die geslagte is die algemeen aanvaarde model van die tyd, naamlik dié van komplementariteit. Hoewel hy wil toegee dat vroue ' $n$ groter reg het tot outonomie en persoonlike ontwikkeling as wat tradisioneel toegelaat is, wil hy ook hê dat vroue in hulle tradisionele rolle ten opsigte van mans bly. Hy hoop dat "ware vroue", wat hulle ware vroulike natuur verstaan, vrywilliglik hulle rol sal opneem om mans by te staan en te ondersteun, sodat mans ten volle hulle manlike self kan wees (kyk Brunner 1952:55-68; 1957:373-380).

Hoewel Karl Barth skerp van Emil Brunnner verskil het oor enige moontlike aanknopingspunt by die mens vir God se reddingsdaad, vind ' $n$ mens by Barth ' $n$ besondere klem op die mens as God se verbondspartner. Hy het die interpretasie van beeld van God as analogia relationis so ontwikkel dat die God-skepsel hiërargie die analngie word vir man-vrou verhoudings (kyk Micks 1982:9-10). Berkouwer (1962:72-73) oordeel vanuit 'n Gereformeerde en nie-dialektiese uitgangspunt dat Barth reg het om die belangrikheid van die man-vrou verhouding in die skeppingsgebeure aan te dui, maar verkeerd om op grond hiervan relasie te sien as die inhoud van wat dit beteken om "beeld van God" te wees. Die verhouding tussen God en mens bestaan vir Barth daarin dat God die mens aanspreek en die mens reageer. Daar is geen verwarring tussen God as transendente Subjek en die mens as subjek nie. Vanweë die sondige natuur van die mens kan die mens nie self op God reageer nie, maar Christus doen dit namens die mens (vgl Buitendag 1986:688). Die hiërargiese ordening van man en vrou in die familie en in die samelewing gaan volgens hom nie oor ' $n$ intrinsieke superioriteit van mans en minderwaardigheid van vroue nie. Tog moet mans en vroue hulle plek en rolle binne God se ordening aanvaar as gehoorsaamheid aan die Goddelike wil (kyk Barth [1939] 1957:169-171). 
Hierdie gebrek by Barth aan ' $n$ visie op ' $n$ konsekwente subjek-subjek interaksie tussen man en vrou is deur die bekende eksegeet en teoloog van die University of Notre Dame, Josephine Ford in haar doktorale proefskrif, getitel Toward an anthropology of mutuality: A critique of Karl Barth's doctrine of male-female order as A and B (1984), uitgewys. In die resente verlede het invloedryke Protestantse teoloë soos Jürgen Moltmann (1985) probeer om die konsep "beeld van God" as analogia relationis te behou en terselfdertyd verby te kom by Barth se hiërargiese ordening van manlik en vroulik as " $\mathrm{A}$ " en "B" (vgl Jewett 1975:33- 43).

Die probleem is egter volgens Ruether (1991:274) dat die konsep analogia relationis die man-vrou relasie wesenlik aan die God-mens relasie by wyse van analogie bind. Die God-mens verhouding kan nooit 'n egalitêre relasie van wederkerigheid wees nie. Daarom slaag die moderne Protestantse konsejp "beeld van God" as analogia relationis nie daarin om vroue ten volle in te sluit in die beeld van God nie. Dit het eerder die basiese tendens in die Christelike tradisie voortgesit om die man "soos God" te maak teenoor die vrou wat die skepping verteenwoordig. Christelike feministiese antropologie aanvaar dat Genesis 1:27 'n egalitêre teks is waarin die vrou, gelyk met die man, die beeld van God verteenwoordig. Dit aanvaar ook meesal dat Galasiërs 3:28 'n parallel is van die moderne individualistiese interpretasie van Genesis 1:27. Soos hierbo (???) aangetoon, kom so ' $n$ lees van die tekste op anachronistiese interpretasie neer.

\section{7. 'N NAWOORD}

Sowel die filosofiese as die teologiese denke van die dag het hulle uitlopers in die lewenspraktyk van mense. Die vraag is watter uitwerking die bo vermelde denkrigtings op die praktiese lewensituasie van vroue gehad het. Sommige denkrigtings lyk asof hulle die potensiaal tot positiewe verandering vir vroue inhou. 'n Voorbeeld hiervan is die liberale tradisie se siening dat alle mense oor dieselfde menslike natuur beskik. Die menslike natuur word gedefinieer as die besit van rede en 'n morele gewete. Die wortels van hierdie definisie van die menslike natuur lê egter in die klassieke Christelike tradisie wat "rede" en "heerskappy" oor die laer domein aan mans toesê. Vroue se vermoé tot redelikheid en morele wil is in die klassieke tradisie gesien as minderwaardig aan die van die man en dit is as rede aangevoer waarom vroue nie leiersposisies kan beklee nie. Aan 
die begin van die twintigste eeu, toe vroue begin toetree het tot universiteite, is daar geredeneer dat die ontwikkeling van die rede vroue se reproduktiewe vermoëns sal skaad (kyk Coll 1994: 75; vgl ook Hall 1916; Ehrenreich \& English 1978:128-130).

Die patriargale wortels van die liberale tradisie het duidelik geword toe burgerregte van vroue weerhou is. Die manlike familiehoof is steeds gesien as die korporatiewe verteenwoordiger van die "menslike natuur": hy verteenwoordig dié wat van hom afhanklik is. Toe 'n latere ontwikkeling vroue wel insluit as een wat reg het op burgerregte, was dit steeds gebaseer op die patriargale gespletenheid tussen huis en samelewing, private sfeer en openbare sfeer. Vroue se gelykheid voor die wet het nou gedien as kamoeflering van hulle voortgesette ekonomiese afhankllikheid in die huis- en werksituasie. Die liberale egalitêre strategie is dus daarop gebaseer om vroue te assimileer in 'n manlike model van mensheid (kyk Ruether 1991:275). Dit verskaf dus nie 'n basis vir egte gelykheid in die praktyk nie, nie in die gesin of in die werksituasie nie.

Romantiese komplementariteit sien manlikheid en vroulikheid as teenoorgestelde nature met verskillende unieke eienskappe. Vroulike eienskappe is geassosieer met private vroomheid en 'n altruistiese moraliteit wat impliseer dat vrou natuurlikerwys meer "Christelik" is as mans, maar wat vroue terselfdertyd relegeer tot ' $n$ ander-wereldse magloosheid (kyk Ruether 1991:276).

In al hierdie filosofiese en teologiese besprekings is dit mans wat met mekaar praat oor vroue. Nouliks het vroue die ruimte om hulleself te definieer en self te sê hoe hulle die Bybel interpreteer of hoe hulle hulle plek en take in die samelewing sien. Die twee-nature antropologie definieer vroue en mans volgens die norme en lewensuitkyk van 'n vergange era. Hierdie norme en siening word gelyk gestel aan God se wil en mag daarom nie verander word nie. "Dualistic thinking strives to maintain the status quo as the natural order fixed by creation - as if what exists is from on high" (Coll 1994:76). Dualistiese denke lei tot 'n gemaklike aanvaarding van die patriargale stelsel, die heerskappy van magtige mans oor minder magtige mans en vroue. Ook dit word gesien as natuurlik, hoe dit behoort te wees as God-gegewe. Die rolle wat die kultuur toeken aan vroue en mans word beskou as deel van God se plan van die begin af.

Sosiale en psigologiese kenmerke van elke geslag is ook God-gegewe en daarom onveranderlik. Die dualistiese antropologie definieer vroue volgens hulle prokreatiewe 
potensiaal. Die vrou se fisiologie bepaal haar hele menswees. Elke faset van haar lewe word bepaal deur haar potensiële vermoë om kinders te baar. Selfs vroue wat nie moeders is nie, word gedefinieer in terme van moederskap. Vroue is geskape om moeders te wees, maar mans is nie geskape om vaders te wees nie (kyk Coll 1994:76-77). Die dualistiese model werk op twee maniere. Die vrou as mindere is die man se helper en daarom is dit reg dat sy hom dien en van hom beskerming ontvang teen die booshede van hierdie wêreld. Aan die ander kant word vroue gesien as komplementêr tot mans. Hulle verskaf die vroulike dimensie waartoe mans nie in staat is nie. Vroue kan omgee en versorgende eienskappe bydra tot die openbare sfeer. Vroue is dus nie in staat om in die wêreld te funksioneer in die rolle wat tradisioneel deur mans vervul is nie. Mans en vroue word deur hierdie siening beperk tot sekere talente, vermoëns en gedrag (vgl Coll 1994:75).

Die feministiese beweging het na vore gekom om vroue se stem ook te laat hoor. Victoriaanse en kontemporêre feministiese strominge het twee verskillende antwoorde gegee op bogenoemde dualistiese antropologie. Die hervormende rigting sien vroue in hulle moederrol as moreel meer hoogstaande as mans. Vroue moet dus die "gevalle" openbare manlike wêreld hervorm van die geweld, onreg en morele korrupsie wat daarin aangetref word (kyk Gifford 1981:294-340). Die separatistiese rigting beskou manlike geweld en onreg as onherstelbaar. Mans het die minderwaardige spesie geword, met 'n skreiende gebrek aan die volle menslike vermoe tot liefde, sorg, omgee en wederkerigheid. Mans is van nature gewelddadige, gevoellose egoïste. Vroue behoort te onttrek aan 'n manlike wêreld en 'n beter eie wêreld skep (kyk Ruether 1991:276). Moderne separatiste sien manlikheid en die patriargale sisteem as die oorsprong van alles wat boos is. Hulle wil ' $n$ aparte gemeenskap van vroue vorm. Die bekendste eksponent hiervan is Mary Daly wat dit soos volg stel: "(S)eparatism is an essential aspect of gynophilic communication, for it separates a woman from the causes of fragmentation - the obstacles, internal and external - which separates her from the flow of integrity within her self" (Daly 1984:370).

Rosemary Ruether is bekend vir haar kritiek op hierdie siening. Volgens haar word die meeste kontemporêre feministe nie aangetrek deur hierdie ouer feministiese tradisies nie. Die feministiese beweging wil juis wegbeweeg van "n dualistiese siening 
van die mens se natuur na 'n een-natuur antropologie. Die verskil tussen die twee sienings kan soos volg saamgevat word: "Dual-nature anthropology suggests that women and men are of different natures determined by God and that these different natures determine what is appropriate for each sex ... (S)ingle-nature theory ... holds that most differences between women and men are culturally defined and therefore open to change" (Coll 1994:70).

Die een-natuur antropologie word "Skriftuurlik" gefundeer in Genesis 1:27. Volgens hierdie siening is daar net één manier om mens te wees, nie 'n manlike manier én 'n vroulike manier nie. Daar is nie vooraf bepaalde rolle of funksies nie. Die enigste werklikheid van verskil is biologies van aard. Volgens die dualistiese siening is persoonlikheids- en psigologiese eienskappe beskryf in terme van teenoorgestelde kategorieè: selfgeldende optrede, onafhanklikheid, moed en rasionaliteit as manlik, en sagtheid, sentimentaliteit en generatiwiteit as vroulik. Moderne navorsing het aan die lig gebring dat baie van wat geoormerk is as "manlik" of "vroulik", kultuurgebonde is (vgl Mead 1939). Coll (1994:80, 81) wys egter op die gevare en beperkings van 'n een-natuur antropologie. Mans het veel meer geleentheid gehad om as persoon te ontwikkel. Vroue, wat 'n agterstand het, loop die gevaar om dan net binne 'n manlike sisteem te leer oorleef. Dit sou vroue se waarde, ervaring en geskiedenis ontken. In die praktyk beteken dit dat die manlike steeds funksioneer as die norm vir menswees. Verder bring so 'n siening nie liggaamlikheid en hormonale verskille wat bydra tot die geslagte se spesifieke ervaring in' en van die werklikheid in berekening nie. Ons weet nog nie wat "vrou" presies behels nie. Al wat ons het, is 'n sosiale konstruk vanuit 'n manlike perspektief en vroue se ontwakende protes daarteen. 'n Androgene model gaan van die standpunt uit dat elke individu eienskappe vertoon wat voorheen aan die geslagte toegeskryf is. Dit suggereer dat mans en vroue gemeenskaplike menslike eienskappe het. Die voordele van so 'n model is dat

... women who are ambitious, initiating and assertive would no longer be perceived as overly masculine and lacking femininity. Nor would men who are gentle, relational, and aesthetic feel that they must make up for these qualities by adopting a macho attitude. Women and men alike might be able 
to perceive themselves as human beings who sometimes act independently as agents and who sometimes act communally.

(Coll 1994:81)

In die algemeen gesien het die feministiese beweging vir 'n uitgebreide eennatuur antropologie gekies. Ruether (1991:276) stel dit soos volg:

(F)eminism has taken its stand on an expanded unitary view of human nature, possessed fully and equally by both men and women. The expanded unitary view brings into the definition of humanness the qualities of sensual and intuitive feeling, altruism and care, along with the capacities for reason and moral will. It seeks to synthesize the two sides of the complementary model in one andogynous humanness, possessed equally by women and men.

Die feministiese beweging verwerp dus sowel die siening van die manlike verteenwoordigende beginsel in die menslike natuur as die dichotomie van komplementariteit, albei gefundeer in 'n dualistiese antropologie. In die moderne feministiese hermeneutiek slaan die bespreking oor die mens, man en vrou, as beeld van God 'n ander rigting in. In die eerste plek word aanvaar dat alle Godsbeelde wat mense konstrueer, gewoon menslike projeksies is. "The definition of God as patriarchal male is presumed to be a projection by patriarchal males of their own self-image and roles, in relation to women and lower nature, upon God. Thus it is not 'man' who is made in God's image, but God who has been made in man's image" (Ruether 1991:277). God is in werklikheid buite bereik van menslike woorde, beelde en begrippe - die mens kan in elk geval net metafories oor God praat en kan God net gedeeltelik uitdruk (vgl McFague [1982] 1985, 1987). Enige poging om God te verbeeld moet dus geskied met groot omsigtigheid, nederigheid en erkenning van die beperkings en die voorlopigheid van só 'n poging. Daar moet 'n sensitiwiteit wees vir hoe hierdie voorlopige verbeelding wat vanuit 'n spesifieke konteks en perspektief gedoen word, ander buite daardie konteks en perspektief affekteer. Daar moet dus 'n bewuswording wees van wanneer die spesifieke manier 
waarop 'n sekere groep God verbeeld, ander mense seermaak of aan hulle menswaardigheid afbreuk doen.

'n Feministiese poging om Godsbeelde te rekonstrueer soek 'n regverdige antropologie as basis. Die Godsbeelde wat gekonstrueer word moet ruimte bied vir die volle verwerkliking van menslike potensiaal vir mans én vroue. Die vraag moet altyd gevra word watter menslike projeksies oor God lei tot onreg en verminderde mensheid en watter projeksies volle mensheid vir alle mense bevorder (Ruether 1991:277). Denkkonstrukte, soos teologiese en antropologiese teorieë, is met ander woorde nie onskuldig nie. In die geskiedenis blyk duidelik hoe dit aan die een kant sosiale strukture beïnvloed het en aan die ander kant dien om sosiale strukture te legitimeer. Kultuur vorm ons menswees. Mense erf die norme en denkwyses van die samelewing en maak dit hulle eie. Dit word deel van hulle selfdefinisie. Dikwels is mense onbewus van die negatiewe kant van wat op die wyse geabsorbeer word. In die geval van vroue spesifiek, verloop die proses van internalisering van negatiewe boodskappe soos volg:

\footnotetext{
Es scheint, daß alle ublichen Vorstellungen über die Frau als das Negative vom Mann oder als seine Gehilfin: "Mutter von ...", "Frau von ...", “Tochter von ...", "Mătresse von ..." mit all ihren entsprechenden sozialen Realităten, die Frauen produziert und reproduziert haben, gebildet wurden, weil dies die Modelle waren, nach denen sie ihre Identităt geformt haben
}

(Mulder 1996:72)

Dit is egter nie net vroue wat skade ly wanneer sisteme ontmenslikend inwerk op mense nie. 'n Ontmenslikende sisteem ontmenslik sowel dié met meer mag as dié met minder mag, net op verskillende wyses. "When the systems operative in a culture are demeaning and dehumanizing, a vicious circle is set in motion in which women and men are prevented from developing the full humanity to which they are called. At the same time fractured humanity is incapable of creating a society that is truly human" (Coll 1994:82).

Juis omdat dit vir mense onmoontlik is om 'n "menslike" samelewing tot stand te bring, is dit volgens die feministiese siening van die grootste belang om krities te kyk en 
nie maar tevrede te wees met 'n ontmenslikende status quo nie. In die belang van outentieke lewe voor God vir alle mense is dit noodsaaklik om te herken en te erken dat denkkonstrukte en sosiale patrone menslike maaksels en nie God-gegewe strukture is nie. Daar is die potensiaal tot kwaad in alle menslike strukture en in alle gebruike van die samelewing. Leroy Howe (1995:23) stel dit so:

Central to a Christian understanding of human existence is the conviction that God is at work re-creating the whole of humanity as a single family whose members share a common calling to care for the created order. But our sense of partnership wanes with the failure to restrain our impulses to dominate, and solidarity with all human beings is everywhere eclipsed by oppression and enslavement. Nevertheless, we continue to yearn for a truly caring society as the harvest of a genuinely meaningful historical process.

Hierdie moontlikheid om seer te maak en skade te doen aan mense moet beveg word. Daarvoor is 'n voortdurende bewuswording nodig. Bewuswording lei tot verandering. Die doel hiervan is dat vroue en mans outentieke lewe voor God kan hê.

'n Volgende vraag wat na vore kom is hoe die gesag van die Bybel in die feministiese teologie en hermeneutiek funksioneer. Ruether het aangetoon dat die moderne siening van beeld van God as egalitêre konsep nie gesubstansieer word as 'n akkurate weergawe van die betekenis van die Hebreeuse teks of die Nuwe-Testamentiese interpretasies daarvan nie. Die Christelike tradisie het vroue alleenlik op ' $n$ androsentriese wyse ingesluit in die beeld van God. Dit is ' $n$ gegewenheid, wat die Bybel betref, wat van meet af aan aanvaar sal moet word. Die androsentriese aard van die konsep "beeld van God" sluip selfs in wanneer moderne teolő probeer om die gelykheid van die geslagte aan te toon. Dus bly daar vir die feministiese rigtings twee moontlikhede oor: of om die Bybel te verwerp of om dit te herinterpreteer op 'n wyse wat die tradisie in die verlede verander en ook die insigte van vandag kan verander.

Die feministiese hermeneutiek kan nie instemming hê met die ortodokse RoomsKatolieke of ortodokse Protestantse sienings oor die verhouding tussen die Skrif en die tradisie nie. Die ortodokse Protestantisme het probeer om by die "oorspronklike" bedoeling van die Skrif uit te kom. Die Skrif is gesien as onfeilbaar, terwyl die tradisie wel 
feilbaar geag is. Volgens Ruether (1991:278) was " $(t)$ his theory ... contradictory from its beginning, since the Christian tradition had originally developed by putting aside parts of Hebrew Scriptures as no longer normative. Thus there has never been any way Christians can claim the whole Bible as equally normative without falling into unacknowledged contradictions." Die histories-kritiese metode se bedoeling was juis aanvanklik om te dien as 'n middel om die "oorspronklike" bedoeling van die teks duidelik te maak. Maar in die proses het hierdie metode juis die beginsel van die "onfeilbaarheid" van die teks ondermyn. Dit het die eksegeet gedwing om die corspronklike konteks van die teks raak te sien.: Die konteks bestaan uit vooronderstellings en 'n wêreldbeeld wat nie noodwendig in latere tye langer onderskryf hoef te word nie.

Die feministiese hermeneutiek gaan van die vooronderstelling uit dat alle menslike denkkonstrukte relatief en feilbaar is. Die werkwyse wat voortspruit uit so 'n vooronderstelling, is dan om 'n duidelike begrip te probeer kry van wat die idees in die Skrif beteken in hulle konteks en in die verskillende kontekste in die verskillende tydperke van die tradisie. Dan kan rekonstruksie plaasvind, 'n nuwe tradisie geskep word, wel wetende dat ook die nuwe tradisie nie onfeilbaar of onveranderlik is nie. In rekonstruksie moet feministiese teoloë eerlik wees oor die defekte van die verlede en oop wees vir kritiek van diegene vir wie volle menswees beperk of ontsê is (Ruether 1991:278279). Ek self kies om die norm te gaan soek by God waarvan die Bybel getuig. As Reformatoriese teoloog steun ek dus op die Bybel, maar nie op die ortodoksie se idee van 'n "onfeilbare" Bybel nie. In die Bybel word meesternarratiewe en kontranarratiewe aangetref. Patriargale magsbelange kan beskou word as deel van die meesternattarief. Hierdie narratief marginaliseer egter vroue se ervaring. Haar outentieke lewe voor God is verhinder as gevolg van manlik-bemiddelde hiëragiese kultuurmaatreëls. God se koms in en deur Jesus toon 'n weg vir alle mense, ook vir die vrou as selfstandige mens, om direk en onbemiddeld in God se teenwoordigheid te lewe. Vir my is die norm nie 'n reduserende historiese Jesus-konstruk nie, maar die aanhoudende soeke na die Jesus-saak wat gaan oor God se onbemiddelde koms na die mens toe. Hierdie Jesus-gebeure het wel ten tye van ' $n$ bepaalde historiese periode en in die konteks van 'n bepaalde kultuur plaasgevind. Kultuurmaatreëls - patriargaal, liberaal, romanties, revolusionêr al dan nie - kan egter nooit wesenlik deel wees van die norm nie. Inteendeel, dit het altyd die neiging om 
die saak waarom dit eintlik gaan, te verberg en te verloor. Daarom is die norm nie in die vind van Jesus nie maar in die soeke na Jesus. Dit is 'n aksioma dat 'n kerk van die Hervorming altyd hervorm moet word. Dit beteken dat strukture voortdurend ondersoek moet word ter wille van die bewuswording van wat verkeerd en skadelik is. Die doel sal altyd wees om wat verkeerd is, reg te stel. Die kerk sal die tydelike pyn wat bewuswording meebring en die ongemak wat verandering veroorsaak, moet trotseer ter wille van die kerk se heiligmaking en heelheid. Wat vroue betref, was en is daar heelwat verwringing ten opsigte van outentieke lewe in sowel die samelewing as die kerk. Pastorale interaksie met vroue wat nie verdere skade berokken of verwringing voortsit nie, maar vir vroue die ruimte skep tot outentieke lewe voor God en vroue in staat stel om aktief daarna te streef en daarna te leef, sal kan bydra tot die restourasie van kerk en samelewing na die bedoeling van Jesus.

\section{Literatuurverwysings}

Barth, K [1939]1957. Christ and Adam: Man and humanity in Romans 5, tr by T A Smail. New York: Macmillan.

Barth, K 1962. Schleiermacher's 'celebration of Christmas,' in Theology and the church. London: SCM.

Berkouwer, G C 1962. Man: The image of God. Grand Rapids, MI: Eerdmans. (Studies in Dogmatics.)

Bonhoeffer, D 1959. Creation and fall: A theological interpretation of Genesis 1-3 (1937). London: SCM.

Børresen, K E 1981. Subordination and equivalence: The nature and role of woman in Augustine and Thomas Aquinas, tr by C H Talbot. Washington, D C: University of America Press.

Bouwsma, W J 1988. John Calvin: A sixteenth century portrait. New York: Oxford University Press.

Brunner, E 1952. The Christian doctrine of creation and redemption. Philadelphia: Westminster.

- 1957. The divine imperative. Philadelphia, PA: Westminster. 
Buber, M 1984. Das dialogische Prinzip: Ich und Du. Zwiesprache. Die Frage an en Einzelnen. Elemente des Zwischenmenschlichen zur Geschichte des dialogischen Prinzips. Heidelberg: Verlag Lambert Schneider. (Lambert Schneider Tassenbùcher.)

Buitendag, J 1986. Die skepping as gelykenis: 'n Beoordeling van die skeppingsleer van Karl Barth in die lig van die appèl van die ekologiese krisis. HTS 42(4), 674-695. Clark, E A 1979. Jerome, Chrysostom, and friends: Essays and translations. New York, Toronto: The Edwin Mellen Press. (Studies in Women and Religion.)

Clark, E \& Richardson, H 1977. Schleiermacher and Baader: Individuality and androgyny, in Women and religion: A feminist sourcebook of Christian thought, 173-190. New York: Harper \& Row.

Clements, K 1987. Friedrich Schleiermacher: Pioneer of modern theology. London: Collins. (The Making of Modern Theology. 19th and 20th Century Theological Texts.)

Coll, R A 1994. Christianity and feminism in conversation. Mystic, CT: Twenty-Third Publications.

Daly, M 1979. Gyn/Ecology: The metaethics of radical feminism. Boston: Beacon.

- 1984. Pure lust: Elemental feminist philosophy. Boston: Beacon Press.

De Vries, D 1996. Oorsigartikel: Richardson, R D 1991, The role of women in the life and thought of the early Schleiermacher (1768-1806): An historical overview, in Epp, E J 1996, Critical review of books in religion, Vol 7 (1994), 551-553. Atlanta, GA: Scholars Press.

Douglas, A 1977. The feminization of American culture. New York: Avon.

Douglass, J D 1991. The image of God in women as seen by Luther and Calvin, in Børresen, K E (ed), Image of God and gender models in Judaeo-Christian tradition. Oslo: Solum Forlag.

Dworkin, A 1974. Woman hating. New York: E P Dutton.

Ebeling, G 1971. Lutherstudien, Band I. Tübingen: J C B Mohr (Paul Siebeck).

Ehrenreich, B \& English, D 1978. For her own good: 150 years of the experts' advice to women. New York: Doubleday. 
Fleisher, M P 1981. “Are women human?" The debate of 1595 between Valens Acidalius and Simon Geddicus. Sixteenth Century Journal 12, 107-120.

Ford, J 1984. Toward an anthropology of mutuality: A critique of Karl Barth's doctrine of male-female order as A and B. PhD dissertation, Northwestern University, June 1984.

Gifford, C 1981. Women in social reform movements, in Ruether, R R \& Keller, R S (eds), Women and religion in America: The nineteenth century, 294-340. San Francisco: Harper \& Row.

Hall, W C 1916. Sexual knowledge. Philadelphia: John C Winston.

Howe, L T 1995. The image of God: A theology for pastoral care and counseling. Nashville: Abingdon.

Jewett, P K 1975. Man as male and female: A study in sexual relations from a theological point of view. Grand Rapids, MI: Eerdmans.

Kelly, J 1982. Early feminist theory and the Querelle des Femmes, 1400-1789. Signs 8, 4-28.

Maclean, I 1980. The Renaissance notion of woman: A study in the fortunes of scholasticism and medical science in European intellectual life. Cambridge: Cambridge University Press.

Massey, M C 1985. Feminine soul: The fate of an ideal. Boston: Beacon.

McFague, S [1982] 1985. Metaphorical theology: Models of God in religious language. Philadelphia: Fortress.

- 1987. Models of God: Theology for an ecological, nuclear age. Philadelphia: Fortress.

Mead, M 1939. Sex and temperament in three primitive societies. New YorkMorrow.

Micks, M H 1982. Our search for identity: Humanity in the image of God. Philadelphia: Fortress.

Moltmann, J 1985. God in creation. San Francisco: Harper \& Row.

Mulder, A C 1996. Überlegungen zur "imago dei”: Minimalisierung oder Maximalisierung der Differenz zwichen den Geschlechtern, in Günter, A (Hrsg), Feministische Theologie und postmodernes Denken: Zur theologischen Relevanz der Geschlechterdifferenz. Stuttgart: Kohlhammer. 
Oberman, H A 1963. The harvest of medieval theology: Gabriel Biel and late Medieval nominalism. Cambridge, MA: Harvard University Press.

Potter, M 1986. Gender equality and gender hierarchy in Calvin's theology. Signs 1, 725-739.

Ruether, R R 1991. Imago Dei, Christian tradition and feminist hermeneutics, in Børresen, K E (ed), Image of God and gender models in Judaeo-Christian tradition. Oslo: Solum Forlag.

Richardson, R D 1991. The role of women in the life and thought of the early Schleiermacher (1768-1806): An historical overview. Lewiston, NY: Edwin Mellen. (Schleiermacher Studies and Translations 7.)

Summers M 1971. Malleus Malificarum, tr by Montaque Summers. New York: Dover. 